\title{
Relation of Lecturer's Competency, Motivation and Utilization of Information and Communication Technologies to Job Satisfaction and Performance
}

\author{
Mirfan M. \\ Assistant Professor of Informatics Management \\ STIMIK Dipanegara Makassar, Indonesia \\ H. Mursalim Umar Gani \\ Professor of Management Science \\ Muslim University of Indonesia \\ Serlin Serang \\ Associate Professor of Management Science \\ Muslim University of Indonesia \\ H. Zaenal Arifin \\ Associate Professor of Management Science \\ Muslim University of Indonesia
}

Received: May 5, 2018

Accepted: May 22, 2018

Published: May 30, 2018

doi:10.5296/wjbm.v4i1.13255

URL: https://doi.org/10.5296/wjbm.v4i1.13255

\begin{abstract}
The purpose of this study was to analyze the relation of competency, motivation and utilization of information and communication technologies (ICT) on job satisfaction and lecturer's performance at five College of informatics management and computer technique in Makassar. This study uses survey data collection Cross section through a questionnaire. As many as 285 lecturers are eligible to be population and determination of a sample of 160 respondents using the formula Slovin. Data from the questionnaires were analyzed using Structural Equation Model (SEM) with AMOS assistance. The results found that the
\end{abstract}




\section{Macrothink}

World Journal of Business and Management

ISSN 2377-4622 2018, Vol. 4, No. 1

competence, motivation and utilization of ICT positive and significant effect on job satisfaction and lecturer performance. Job satisfaction has a positive and significant effect on the lecturer's performance. Competence, motivation and ICT have a positive and significant effect on lecturer's performance through job satisfaction.

Keywords: Competence, Motivation, Information technology, Job satisfaction, Performance 


\section{Introduction}

Modern management paradigm and professional education requires educational institutions, especially higher education to function effectively through the learning process, curriculum and community involvement as part of the control mechanism of the existence of the world of education. One of the parties that play a strategic role in improving the progress and quality of these institutions is the performance of lecturer. Lecturer is one of the essential components of an educational system in colleges. Even related to duties and responsibilities, the role of the lecturer is very important in realizing the goal of national education, educating the nation; improving the quality of human Indonesia including the quality of faith and piety, morality, and mastery of science, technology and art, and to bring people of Indonesia who developed, fair, prosperous and civilized.

Lecturer mentioned as a professional educator and scientist with the main task of transforming, developing and disseminating science, technology and the arts through education, research and community service. As scientists, professors must have the motivation to work, have the academic skills to writing skills, and have the ability to insert an article in a scientific journal (Law of the Republic of Indonesia Number 14 of 2005). Although the implementation and fulfillment of work assignments, faculty faced some problems in between issues of professionalism. Indonesia Lecturers Association report of 2009 mentions the majority of Indonesian lecturers have not been carrying out a duty well. This is because most professors still make a profession of lecturers as a status symbol that is not occupied as other professions. Lecturer professionalism interference due to inadequate salaries, lecturer became official at the government institutions to reduce interest in becoming professors, and others became businessmen, traders resulting in the lack of time they need to prepare for teaching.

Three Principles of Higher Education (Tri Dharma) the duties of lecturers: education or teaching, research and community service has not been implemented with good high school information management in the city of Makassar, which is within the Private High Education Coordinator Region IX Sulawesi (KOPERTIS) consists of five College of informatics management and computer technique with a number of professors 285 lecturers and 5.081 students. The lecturer performance of College of informatics management and computer technique in Makassar still not up because of some lecturers still educated bachelor and others in the settlement process master of science and doctoral. In addition to the research activities and community service performed lecturers is also still less do. Another phenomenon associated with the performance of lecturers due to low salaries received, causing a lecturer looking for additional income such as entrepreneurship, Information technology consultants, online driver and other activities to meet their needs. The conditions show that the faculty job satisfaction is low. In addition to employee motivation, a factor which may also increase job satisfaction is the competency of lecturers.

Proper competence can lead to great enthusiasm and high morale in completing the work. Facts on the ground show still found some lecturers who do not have the competency are qualified, good pedagogical, professional competence, personal competence and social 
competence. Definition of performance refers to the performance of the individual, which is a result achieved by the worker in his job according to certain criteria that apply for a particular job. Individual performance is described as an individual performance that is governed by standards or criteria established by an organization. Based on the above understanding can be concluded that the performance or often referred to as the job performance or job performance is the quality and quantity of a work of individuals in a certain activity and by size that apply to the job in question. This size is determined by the organization designated as a target in one period (Engko, 2006).

The task of the lecturer stated in the Law of the Republic of Indonesia No. 14 of 2005 on teachers and lecturers, including (a) implement the education, research and development of science and community services (b) plan, implement the learning process and assess and evaluate the learning outcomes, (c) promote and develop academic qualifications and competence on an ongoing basis in line with the development of science technology and art. Implementation tasks in a professional lecturer under the provisions of the Directorate of Higher Education of the Republic of Indonesia issued guidance faculty workload that must be implemented in a single semester.

Faculty workload is the amount of work assigned by the leadership of the college and or additional tasks in a certain period measured in semester credit (SKS), which includes; (1) Education, (2) Research and development of science, (3) Field of community service, and (4) supporting the Three Principles of Higher Education. Ideally of the lecturer workload in implementing by the three principles of higher education at least of 12 credits and a maximum of 16 credits in each semester according to the academic qualification. Thus the performance of the task of the achievements of faculty is a lecturer in performing a number of tasks Three Principles of Higher Education has the duty and responsibility for one semester. Empirical evidence suggests that in addition to the competence and motivation, other factors that can affect the performance of the individual is the use of information technology (Goodhue \& Thomson, 1995) provides empirical evidence on the performance of individual ties with the task of matching technology. In the study stated that the performance related to the achievement of individual tasks supported by existing technology. The development of information and communication technology has brought changes so great for education. At least five shifts in the world of education, namely the shift from training to performance, a shift from the classroom to the virtual space and the shift from physical facilities to network facilities, and a shift from real-time to the cycle time (Sundaram, 2007).

\section{Literature Review and Hypothesis}

\subsection{Competence, Job Satisfaction and Lecturer's Performance}

Competence is a combination of pedagogical knowledge, professional skills, the value of personality and social interaction which is reflected in one's ability, so it looks understand, master, practice and being able to interact in doing work that occupied. Means competence can be defined as the ability of a person to take advantage of all the ability to do the work according to the desired destination (Chamorro-Premuzic \& Arteche, 2008). Competence can be explained by characteristics (Wirawan, 2009; Mulyasa, 2011), namely (a) pedagogic 
knowledge of the ability of a person for the work performed; (b) of the ability of skilled professionals in doing a good job; (c) the personality of the ability of the motives and behavior of a person in the work; and (d) social interaction in the form of self-concept in doing the job.

Indonesian Government Regulation No. 19 Year 2005 on National Education Standards to Article 28, paragraph 3 states that the competencies that must be owned by a professor as a learning agent is: (a) Competence pedagogy is the ability to manage learning students include an understanding of the learners, the design and implementation learning, evaluation of learning outcomes, and the development of students to actualize its competence; (b) Professional competence is the ability of mastering learning materials widely and deeply that enable guide students to meet the standards of competence specified; (c) The personality competence is the ability of personality steady, stable, mature, wise and authoritative, become role models for students and noble; (d) Social competence is the ability of educators as part of the community to communicate and interact effectively with the academic community.

Competence is the key to obtaining job satisfaction and performance of lecturers optimal, that competence significant positive effect on job satisfaction and performance (Abusama et al., 2017; Sriekaningsih, \& Setyadi, 2015; Hakim, 2015; Lucky \& Yusoff, 2015; Nasir et al., 2017; Simanjuntak \& Ritonga, 2018; Huda \& Rates, 2018). The findings were obtained denials from other researchers that the competence of lecturers had no significant effect on job satisfaction (Arifin, 2014) and student academic performance (Prasetio et al., 2017). Therefore, it is hypothesized that:

H1. Competence is positively related to job satisfaction.

H2. Competence is positively related to lecturer's performance.

\subsection{Work Motivation, Job Satisfaction and Lecturer's Performance}

Work motivation is the power or encouragement and concepts necessary for attainment of employment objectives. The purpose of directed can work if there is effort, the energy released at the time of a person doing the work, have clear work objectives and the requirement for someone to arouse the attention to his work. Motivation is a desire in a person that causes the person to take action (Mathis \& Jackson, 2006; Sjahruddin \& Normijati, 2013). Work motivation is a group of factors that cause people to behave in certain ways (Mathis \& Jackson, 2006). Motivation refers to the internal forces and external someone who generates enthusiasm and resistance to perform a series of specific actions. Motivation is the driving force that led to the organization's members are willing and willing to take the time to organize various activities which it is responsible and fulfill its obligations in order to achieve goals and objectives of the organization are predetermined (Siagian, 2003).

Past studies showed that motivation shown by granting rewards and recognition, supervision and work in partial effect on job satisfaction (Shah et al., 2012). The study differs from other research findings that employee motivation is composed of client service, teamwork, employee relationships, employee responsibility, employee behavior and attitude does not 
affect the turnover (Sajjad et al., 2013). Lecturer motivation shown a significant effect on job satisfaction and performance of lecturer (Wahyu et al., 2014; Lee et al., 2014; Mafini \& Dlodlo, 2014; Sriekaningsih, \& Setyadi, 2015; Gairola, 2015; Theoharis et al., 2016; Nasir et al., 2017; Simanjuntak \& Ritonga, 2018). The results show that the motivation to work more significantly to job satisfaction but not significant to the performance of teachers (Arifin, 2014). Therefore, it is hypothesized that:

H3. Work motivation is positively related to job satisfaction.

$H 4$. Work motivation is positively related to lecturer's performance.

2.3 Utilization of Information and Communication Technologies (ICT), Job Satisfaction and Lecturer's Performance

ICT is seen as a tool used by individuals to help perform tasks in the evaluation. In this context, information technology includes Computer, software, databases, Networks (Internet and intranet), electronic commerce, and other related types of technology (Basu \& Fernald, 2008). Other scholars explain the view of information technology is defined as the science in the field of computer-based information and development is very rapid (Lantip \& Rianto, 2011). In addition to information technology as computer Technology (software and hardware) for the processing and storage of information, it also serves as a communication technology for the dissemination of information.

Computer as one component of information technology is a tool that can magnify the ability of human beings and computers are also able to do something that humans may not be able to do so. Information technology aim is to solve problems, unlock the creativity and increasing the effectiveness and efficiency of doing the job (Sutabri, 2014). The empirical findings provide evidence that maximum utilization of information technology proven to improve the performance of the company (Luftman et al., 2017). In the context of entrepreneurship showed that the role of ICT has no significant effect on employee's performance in the workplace (Rusdi et al., 2017). Therefore, it is hypothesized that:

H5. Utilization of ICT is positively related to job satisfaction.

H6. Utilization of ICT is positively related to lecturer's performance.

\subsection{Job Satisfaction and Lecturer's Performance}

Job satisfaction is a positive attitude regarding a healthy adjustment of the employees of the conditions and the employment situation, including the issue of wages, social conditions, physical and psychological condition (Anoraga, 2006). The views of other scholars explain job satisfaction is an effective or emotional response to various aspects of the work (Kreitner $\&$ Kinicki, 2000). The aspects that affect job satisfaction which aspects of the feelings associated with employment such as wages or salary received, opportunities for career development, relationship with other individuals, while aspects they relate to, among other things age, health condition, abilities, and education (Mangkunagara, 2004).

Job satisfaction is only realized if someone runs the organization's activities in accordance 
with the dynamics of the work going on to make the disclosure of feeling by the level of assessment of the job responsibilities, work progress, achievement, recognition and the work itself which gives satisfaction to human resources in the work (Hersey et al., 2007). There are differences in the disclosure of satisfied and dissatisfied at the individual, individuals who are dissatisfied usually reveal the fulfillment of desires and expectations, while individuals who are dissatisfied generally expressed disappointment, resentment and hatred of something (Toban \& Sjahruddin, 2016).

One's satisfaction in work is determined by factors of maintenance in the form of satisfied and dissatisfied, which is interpreted in the form of: (a) responsibility, (b) advancement, (c) achievement, (d) recognition, (e) work itself (Robbins, 2006), The empirical evidence shows that job satisfaction is proven to improve individual performance ( $\mathrm{Fu} \&$ Deshpande, 2014; Atmojo, 2015; Yuen et al., 2018). The higher levels of employee job satisfaction are associated with higher levels of organizational performance (Muterera et al., 2018). Other studies put job satisfaction as mediating variables provide new evidence that job satisfaction found to mediate the relationship between positive psychological capital and job performance (Durrah et al., 2017). Other findings talent management explained that impact job performance, but job satisfaction through the acts as a mediator. Thus, it is not postulated that we have to pursue job satisfaction as a play in underlying contributor to job performance, but rather that if we develop and institutionalize a comprehensively talent system, this can Affect both job satisfaction and job performance (Luna-Arocas \& Morley, 2015). Other results showed that job satisfaction significantly affected job performance. Furthermore, overall job satisfaction is fully mediated the relationship between meaning and job performance. In contrast, job satisfaction partially mediated the relationships between competence and job performance, between self-determination and job performance, and between impact and job performance (Ölçer \& Florescu, 2015). Therefore, it is hypothesized that:

H7. Job satisfaction is positively related to lecturer's performance.

H8. Job satisfaction mediates the positive relationship between competence and lecturer's performance.

H9. Job satisfaction mediates the positive relationship between work motivation and lecturer's performance.

H10. Job satisfaction mediates the positive relationship between utilization of ICT and lecturer's performance.

\section{Methods}

This research is an explanatory Research which attempts to explain causality relationship and to test and confirm the relationship between variables. The population in this study is all professors who teach on five College of informatics management and computer technique In Makassar using a sample of 160 professors. Proving the hypothesis is done by using a structural equation modeling (SEM) with AMOS assistance 21. 


\section{Mll Macrothink

\section{Results}

\subsection{Respondents}

Table 1. The main characteristics of the sample

\begin{tabular}{|c|c|c|}
\hline Characteristics & Frequency $(n=160)$ & Percent \\
\hline \multicolumn{3}{|l|}{ Gender } \\
\hline Male & 91 & 56,87 \\
\hline Female & 69 & 43,13 \\
\hline \multicolumn{3}{|l|}{ Ages } \\
\hline $0-29$ Years & 43 & 27,18 \\
\hline 31 - 39 Years & 57 & 34,96 \\
\hline $40-49$ Years & 41 & 25,72 \\
\hline$>50$ Years & 19 & 12,14 \\
\hline \multicolumn{3}{|l|}{ Functional Position } \\
\hline Instructor & 65 & 40,62 \\
\hline Assistant Professor & 55 & 34,46 \\
\hline Associate Professor & 40 & 25,24 \\
\hline \multicolumn{3}{|l|}{ Job tenure } \\
\hline $0-5$ Years & 60 & 37,57 \\
\hline $6-9$ Years & 64 & 39,81 \\
\hline $10-19$ Years & 24 & 15,04 \\
\hline$>20$ Years & 12 & 7,28 \\
\hline \multicolumn{3}{|l|}{ Education level } \\
\hline Magister of science & 147 & 91,87 \\
\hline Doctor & 23 & 8,13 \\
\hline
\end{tabular}

The respondents characteristics shows that in general respondents gender boys are 91 people or $56.87 \%$, of respondents with ages $31-40$ years as many as 57 people or $34.96 \%$, of respondents by functional reflected on Instructor as many as 65 respondents or $40.62 \%$, of respondents by job tenure dominant in 6-10 years as many as 64 people or $39.81 \%$, and respondents by education indicated by the level of Master of science as much as 147 people or $91.87 \%$.

\subsection{Variable Description}

\subsubsection{Lecturer Competence}

Respondents on average obtained a value of 3.83 and Cranach's Alpha value of 0.854 , the condition shows that the competence of lecturers is high. The average value and the loading factor measurements can be shown in the following table: 
Table 2. Lecturer competence

\begin{tabular}{lcccc}
\hline Measurements & Mean & Correlation & LDF $(\lambda)$ & P-value \\
\hline Pedagogic & 3.61 & 0.85 & 0.80 & 0,000 \\
Professional & 3,65 & 0,78 & 0,71 & 0,000 \\
Personality & 3.51 & 0.80 & 0.69 & 0.000 \\
Social & 3.76 & 0.90 & 0.88 & 0.000 \\
\hline
\end{tabular}

\subsubsection{Work Motivation}

Responder in the average obtained a value of 3.62 and Cronbach's alpha value of 0.83 , the condition showed that motivation shown lecturer is high. The average value and the loading factor measurements can be shown in the following the table:

Table 3. Work motivation

\begin{tabular}{lcccc}
\hline Measurements & Mean & Correlation & LDF $(\lambda)$ & P-value \\
\hline Physiological needs & 3.72 & 0.79 & 0.71 & 0.000 \\
Security needs & 3.59 & 0.76 & 0.67 & 0.000 \\
Social needs & 3.56 & 0.77 & 0.72 & 0.000 \\
Esteem needs & 3.68 & 0.80 & 0.77 & 0.000 \\
Self-Actualization needs & 3.56 & 0.753 & 0,67 & 0.000 \\
\hline
\end{tabular}

\subsubsection{Utilization of ICT}

Respondents on average obtained a value of 3.38 and Cronbach's alpha value of 0.77 , the condition showed that the Utilization of ICT used is high. The average value and the loading factor measurements can be shown in the following the table:

Table 4. Utilization of information technology

\begin{tabular}{lcccc}
\hline Measurements & Mean & Correlation & LDF $(\lambda)$ & P-value \\
\hline Hardware & 3.25 & 0.81 & 0.69 & 0.000 \\
Software & 3.57 & 0.84 & 0.78 & 0.000 \\
Internet & 3.33 & 0.82 & 0.70 & 0.000 \\
\hline
\end{tabular}

\subsubsection{Job Satisfaction}

Respondents on average obtained a value of 3.74 and Cronbach's alpha value of 0.67 ; these conditions show that job satisfaction is high featured lecturer. The average value and the loading factor measurements can be shown in the following the table: 
Table 5. Job satisfaction

\begin{tabular}{lcccc}
\hline Measurements & Mean & Correlation & LDF $(\lambda)$ & P-value \\
\hline Responsibilities & 3.86 & 0.56 & 0.44 & 0,000 \\
Progress & 3,81 & 0,68 & 0,61 & 0.000 \\
Achievements & 3.56 & 0.64 & 0.58 & 0.000 \\
Recognition & 3.51 & 0.72 & 0.55 & 0.000 \\
The work itself & 3,47 & 0.72 & 0.64 & 0,000 \\
\hline
\end{tabular}

\subsubsection{Lecturer Performance}

Respondents on average obtained a value of 3.29 and Cronbach's alpha value of 0.82 , the condition shows that the performance shown lecturer is high. The average value and the loading factor measurements can be shown in the following the table:

Table 6. Lecturer performance

\begin{tabular}{lcccc}
\hline Measurements & Mean & Correlation & LDF $(\lambda)$ & P-value \\
\hline Education and teaching & 3.30 & 0.79 & 0.69 & 0,000 \\
Research and development & 3,22 & 0,78 & 0,71 & 0,000 \\
Community Services & 3.36 & 0.85 & 0,78 & 0.000 \\
Supporting the Three Principles of Higher Education & 3.07 & 0.81 & 0,76 & 0,000 \\
\hline
\end{tabular}

\subsection{SEM Analyzes}

Test results for the model based on the goodness of fit indices in table 7 shows the criteria for a model seen meet conformance testing data.

Table 7. Goodness of fit overall model

\begin{tabular}{cccc}
\hline Goodness of fit index & Cut-off Value & Results Model * & Remarks \\
\hline$\chi^{2}-$ Chi-square & Expected to be Small & $201,244(0,05: 170=201,423)$ & Good \\
Probability & $\geq 0.05$ & 0.01 & Good \\
CMIN/DF & $\leq 2.00$ & 1.18 & Good \\
RMSEA & $\leq 0.08$ & 0.03 & Good \\
GFI & $\geq 0.90$ & 0.90 & Good \\
AGFI & $\geq 0.90$ & 0.86 & Marginal \\
CFI & $\geq 0.94$ & 0.97 & Good \\
TLI & $\geq 0.94$ & 0.97 & Good \\
\hline
\end{tabular}




\subsubsection{The Effect of Lecturer Competence on Job Satisfaction}

Competence is positively related to job satisfaction can be demonstrated by the standardized regression weight estimate value of 0.472 with a positive direction. Coefficients marked positive influence means that the high competences of lecturers directly tend to increase job satisfaction lecturers towards high. Then can also be proven by the value of the critical ratio = $4.862>2.00$ and a probability value of $0.000<\alpha=0.05$. The first hypothesis testing results prove that the competence of lecturers positive and significant impact on job satisfaction. It was concluded that the increase in the positive direction of the lecturer's competence and proven to increase job satisfaction of teachers, so that the first hypothesis proposed in this research that the higher the competence of lecturers resulting in higher job satisfaction lecturers. It can be concluded that if the professor is able to produce a high competence then direct these conditions can increase the job satisfaction of teachers so the hypothesis can be accepted or supported by empirical facts.

The condition is caused due to lecturers have high social competence and demonstrated the ability of faculty to understand itself as an integral part of society. This means that the competence of lecturers in this master and is able to design a learning process for implementing the Three Principles of Higher Education and is also able to contribute to increasing job satisfaction felt by the lecturer. Competence is one of the variables that can affect the high or low of perceived job satisfaction lecturer in conducting the Three Principles of Higher Education so that competence should be considered as an instrument of policy in influencing satisfaction of the lecturer. These findings support previous research findings, that competence is the key to gain job satisfaction and optimal performance of lecturers, that competence significant positive effect on job satisfaction and performance (Abusama et al., 2017; Nasir et al., 2017). The findings were obtained denials from other researchers that the competence of lecturers had no significant effect on job satisfaction (Arifin, 2014).

\subsubsection{The Effect of Competence on Lecturer's Performance}

Competence is positively related to lecturer's performance can be demonstrated by the standardized regression weight estimate value of 0.356 with a positive direction. Coefficients marked positive influence means that the high competences of lecturers directly tend to improve the performance of lecturers towards high. Then can also be proven by the value of the critical ratio $=5.035>2.00$ and a probability value of $0.000<\alpha=0.05$. The second hypothesis testing results prove that the lecturers competence positive and significant effect on the lecturers performance. It was concluded that the increase in the positive direction of the lecturer's competence and proven to improve the performance of teachers, so that the second hypothesis proposed in this research that the higher the competence of lecturers resulting in higher performance shown lecturer. It can be concluded that if the professor is able to demonstrate high competence in implementing the Three Principles of Higher Education then direct these conditions can improve the performance of teachers so the hypothesis can be accepted or supported by empirical facts.

A professor is required to have the ability to socialize well and engage and reward to the academic community and with the community. Lecturers can create success in their work by 
improving the competence, both through formal and informal education. From the analysis above suggests that the learning process in the classroom lecturers usually improvise in terms of the use of means of support or create a classroom atmosphere to be comfortable through the provision of games when teaching to make students more eager to accept the transformation of knowledge to the fullest. These findings support the findings of previous investigators, that competence is the key to gain job satisfaction and performance of lecturers optimal, that competence positive and significant effect on lecturer performance (Abusama et al., 2017; Sriekaningsih \& Setyadi, 2015; Hakim, 2015; Lucky \& Yusoff, 2015; Nasir et al., 2017; Simanjuntak \& Ritonga, 2018; Huda \& Laju, 2018). The findings were obtained denials from other researchers that the competence of lecturers had no significant effect on job satisfaction (Arifin, 2014) and student academic performance (Prasetio et al., 2017).

\subsubsection{The Effect of Work Motivation on Lecturer's Job Satisfaction}

Work motivation is positively related to job satisfaction can be evidenced by the standardized regression weight estimate value of 0.344 with a positive direction. Coefficients marked positive effect means that a high motivation to work directly lecturers tend to increase lecturers job satisfaction towards high. Then can also be proven by the value of the critical ratio $=3.438>2.00$ and a probability value of $0.000<\alpha=0.05$. The third hypothesis testing results prove that work motivation positive and significant impact on job satisfaction lecturers. It was concluded that the increase in the positive direction of faculty work motivation and proven to increase job satisfaction lecturers, so that the third hypothesis proposed in this research that the higher work motivation of lecturers shown lecturer resulted in higher job satisfaction felt by teachers so the hypothesis can be accepted or supported by empirical facts. Lecturers were given the opportunity to actualize their work proved capable of providing its own job satisfaction to the faculty. This will have the effect of faculty to work closely with the entire academic community to prioritize the achievement of maximum results.

Each activity lecture into credit points for lecturers to obtain the nomination of a promotion, because it is very important for professors to be given opportunities in education and training in enhancing the feeling of satisfaction in the work. The results support some empirical evidence that motivation shown by granting rewards and recognition, supervision and the work of a significant effect on job satisfaction (Shah et al., 2012). The study differs from other research findings that employee motivation is composed of client service, teamwork, employee relationships, employee responsibility, employee behavior and attitude has no effect on job satisfaction shown by turnover (Sajjad et al., 2013). Lecturer motivation shown a significant effect on job satisfaction (Wahyuni, 2014; Lee et al., 2014; Mafini \& Dlodlo, 2014; Gairola, 2015; Theoharis et al., 2017; Nasir et al., 2017).

\subsubsection{The Effect of Work Motivation on Lecturer's Performance}

Work motivation is positively related to lecturer's performance can be evidenced by the standardized regression weight estimate value of 0.274 with a positive direction. Coefficients marked positive effect means that a high motivation to work directly lecturers tend to improve the lecturers performance towards high. Then can also be proven by the value of the critical ratio $=4.275>2.00$ and a probability value of $0.000<\alpha=0.05$. The fourth hypothesis 
testing results prove that work motivation positive and significant effect on the lecturers performance. It was concluded that the increase in the positive direction of faculty work motivation and proven to improve the performance of teachers, so that the fourth hypothesis proposed in this research that the higher work motivation of lecturers shown lecturer resulted in higher performance shown lecturers so that hypothesis can be accepted or supported by empirical facts. This illustrates that the motivation which is reflected in the compensation and the incentive is an indicator that is dominant in shaping the work motivation is high, it means a form of material given to lecturers as fringe benefits and additional earnings are still indicators that can provide a motivating force of its own to the lecturers.

Providing incentives as a form of motivation given as remuneration and additional salaries to the work that has been carried out in accordance with the principal task of the lecturer was able to provide its own spirit to the faculty in order to always maintain and increase the motivation of their work so that the performance they produce can be achieved with good. This study supports the findings of work motivation shown lecturer significant effect on job satisfaction and performance of lecturer (Wahyuni et al., 2014; Sriekaningsih \& Setyadi, 2015; Gairola, 2015; Theoharis et al., 2016; Nasir et al., 2017; Simanjuntak \& Ritonga, 2018). Results are obtained denials from other researchers, that motivation is not significant to the teacher's performance (Arifin, 2014).

\subsubsection{The Effect of Utilization of ICT on Job Satisfaction}

Utilization of ICT is positively related to job satisfaction can be evidenced by the standardized regression weight estimate value of 0,277 with a positive direction. Coefficients marked positive influence means that the optimal use of ICT provides improved lecturers job satisfaction towards high. Then can also be proven by the value of the critical ratio $=2.829>$ 2.00 and a probability value of $0.005<\alpha=0.05$. The fifth hypothesis testing results prove that the use of ICT positive and significant effect on job satisfaction. The high utilization of information technology in the direction of the positive and proven to increase job satisfaction felt by faculty, so the hypothesis fifth proposed in this study that the higher utilization of information technology shown lecturer during this resulted in higher job satisfaction felt by teachers so the hypothesis can be accepted or supported by empirical facts.

Use of information technology is one of the variables that can affect the high or low of faculty job satisfaction, for the university as an institution applying information technology should provide optimal information technology and sustainable to the academic community that job satisfaction felt by faculty can be improved. The results of this study support the findings of previous researchers that the most significant motivational factors they reported were internal and personal ones related to the direct benefits of ICT in terms of enhancing Reviews their teaching practice, enhancing students' learning, and improving Reviews their job satisfaction (Gasaymeh et al., 2017). Results are obtained denials from other researchers, that the utilization of information technology no significant effect on job satisfaction (Amazue, 2017).

\subsubsection{The Effect of Utilization of ICT on Lecturer's Performance}

Utilization of ICT is positively related to lecturer's performance can be evidenced by the 
standardized regression weight estimate value of 0,258 with a positive direction. Coefficients marked positive influence means that the optimal use of information technology provides improved performance towards high lecturer. Then can also be proven by the value of the critical ratio $=2.829>2.00$ and a probability value of $0.000<\alpha=0.05$. The sixth hypothesis testing results prove that the use of ICT positive and significant effect on the lecturers performance.

The high utilization of ICT in the direction of the positive and proven to increase job satisfaction felt by faculty, so the hypothesis sixth proposed in this study that the higher utilization of information technology shown lecturer during this resulted in the higher performance of the lecturers so that hypothesis can be accepted or supported by the facts empirical. Use of information technology is a necessity and needs of the faculty, current information technology is already considered an easy task. College as an educational institution should in any activity using information technology utilization and prepare existence of information technology on an ongoing basis and make it as a spearhead in the activities of the academic community to realize the faculty job satisfaction is high. The empirical findings provide evidence that maximum utilization of information technology proven to improve the performance of the company (Luftman et al., 2017). In the entrepreneurship context in Malaysia showed that the role of ICT has no significant relationship with the employee's performance in the workplace (Rusdi et al., 2017).

\subsubsection{The Effect of Job Satisfaction on Lecturer's Performance}

Job satisfaction is positively related to lecturer's performance can be evidenced by the standardized regression weight estimate value of 0,506 with a positive direction. Coefficients marked positive influence means that job satisfaction felt by lecturers contributes to the improvement in the lecturer's performance towards high. Then can also be proven by the value of the critical ratio $=4.699>2.00$ and a probability value of $0.000<\alpha=0.05$. Seventh hypothesis testing results prove that the perceived job satisfaction lecturer positive and significant impact on the lecturers performance. Creation of job satisfaction of faculty due to the high organizational support and the support of the boss of the opportunity of self-development and career as well as the adequacy of income given that then impact on the ease of using the infrastructure provided and harmonious labor relations as well as the recognition of the achievements and equitable justice to enhancement of faculty performance by doing justice to the amount of equalization Three Principles of Higher Education conducted, both the quality and quantity of the teaching is done by considering the efficiency and effectiveness of the Three Principles of Higher Education carried out by each lecturer.

The provision of adequate salaries and bonuses and the provision of adequate protection to the lecturers to do the job or the provision of certain structural positions are appropriate and job placement in accordance with one's abilities, will give a sense of security and satisfaction for lecturers in the works. Thus voluntarily lecturers will be motivated and responsible in their work which will impact on the improvement or performance improvement. The results of this study support the findings of some previous researchers, that job satisfaction significantly influences the performance of lecturers (Atmojo, 2015; Fu \& Deshpande, 2014; 
Yuen et al., 2018). Other results prove that the higher levels of employee job satisfaction are associated with higher levels of organizational performance (Muterera et al. 2018).

4.3.8 The Effect of Competence and Lecturer's Performance: The Mediating Role of Job Satisfaction

Job satisfaction mediates the positive relationship between competence and lecturer's performance, the positive relationship between competence and lecturer performance. Sobel testing results show that the critical ratio $=3.389>2.00$ and a probability value of $0.000<\alpha=$ 0.05. These results show that with the support of job satisfaction, then indirectly competencies proven to improve the performance of lecturers. Organizational support in the form of salary and working safety assurance is an important factor in increasing job satisfaction. The results of this study support previous research, that impact job performance talent management, job satisfaction but through which acts as a mediator. Thus, it is not postulated that we have to pursue job satisfaction as a play in underlying contributor to job performance, but rather that if we develop and institutionalise a comprehensively talent system, this can Affect both job satisfaction and job performance (Luna-Arocas \& Morley, 2015).

4.3.9 The Effect of Work Motivation and Lecturer's Performance: The Mediating Role of Job Satisfaction

Job satisfaction mediates the positive relationship between work motivation and lecturer's performance, the positive relationship between work motivation and lecturer performance. Sobel testing results show that the critical ratio $=2.775>2.00$ and a probability value of $0.005<\alpha=0.05$. These results indicate that indirect job satisfaction proved able to explain the influence of work motivation on the performance of lecturers. This reflects that with the support of the creation of job satisfaction felt by the high motivation to further improve the performance of lecturers towards high. Work motivation based on the compensation and the incentive is high motivation forming means to form from material given to lecturers as fringe benefits and additional revenue is proven to improve the performance of lecturers.

Individuals motivated always analyzing the amount of incentives received from the acts committed. Means the incentive to trigger a person do to motivate you to achieve. Incentives can be defined as the analysis of motivation. Without a major motivation or strong, it cannot achieve optimal results as the value of the incentives for the work performed. People have always been motivated by considering the incentives received in accordance with the achievement of the work. The results of this study support the findings of previous investigators, which Job satisfaction found to mediate the relationship between positive psychological capital and job performance (Durrah et al., 2017).

4.3.10 The Effect of Utilization of ICT and Lecturer's Performance: The Mediating Role of Job Satisfaction

Job satisfaction mediates the positive relationship between utilization of ICT and lecturer's performance, the positive relationship between utilization of ICT and lecturer performance. Sobel testing results show that the critical ratio $=2.413>2.00$ and a probability value of 
$0.015<\alpha=0.05$. These results indicate that indirect job satisfaction proved to be able to explain the effect of utilization of ICT on the lecturers' performance. Demands that must be implemented universities in the implementation of the learning process that utilizes information technology resulted in the college seeks to prepare the infrastructure is sufficient to lecturers in carrying out its activities.

Universities contributions lead to higher perceived satisfaction lecturer, so with a sense of satisfaction experienced an important contribution in improving the performance of lecturers. The results of this study are relevant to the findings of previous research, that job satisfaction significantly affected job performance. Furthermore, overall job satisfaction is fully mediated the relationship between meaning and job performance. In contrast, job satisfaction partially mediated the relationships between competence and job performance, between self-determination and job performance, and between impact and job performance (Ölçer \& Florescu, 2015).

\section{Conclusion}

Competence displayed by the lecturer in the form of competence or ability pedagogic, professional competence, personal competence and social competence of the community, students and co-workers possessed significant faculty contributes to job satisfaction and performance of lecturers. The facts relevant to the same conditions showed that motivation of lecturers form physiological, security, social, esteem, and self-actualization needs that are owned by the lecturer to contribute to the effort to realize increased job satisfaction and performance of lecturers. In another part demonstrated that the optimal use of information technology is evidenced by the high level of utilization in the use of hardware, software and network computers as needed to give adequate real and meaningful contribution to job satisfaction and performance of lecturers.

Job satisfaction is realized with the responsibility, the progress in the process of learning, achievement, recognition of leadership and work as a priority in performing tasks and activities as a lecturer made a real contribution to the performance of lecturers. Serious efforts are needed from the university leaders to improve the competence and motivation as well as the utilization of information and communication technologies in improving the performance of lecturers through faculty job satisfaction. Limitations of this study lies in the unit of analysis used are lecturers who only served on five College of informatics management and computer technique in Makassar thus be limited in explaining the research results

\section{References}

Abusama, M., Haming, M., \& Hamzah, M. N. (2017). Effect of motivation, competence and Islamic leadership on job satisfaction and Teacher performance in vocational high school.

Amazue, L. O. (2017). Roles of Information and Communication Technology and Gender in Job Satisfaction among University of Nigeria Lecturers. Nigerian Journal of Psychological Research, 6(1).

Anoraga, P. (2006). Work Psychology. Jakarta: PT. Rineka Copyright. 
Arifin, H. M. (2014). The influence of competence, motivation, and organizational culture to high school teacher job satisfaction and performance. International Education Studies, 8(1), 38 .

Atmojo, M. (2015). The influence of transformational leadership on job satisfaction, organizational commitment, and employee performance. International Research Journal of Business Studies, 5(2).

Basu, S., \& Fernald, J. (2008). Information and communications technology as a general purpose technology: Evidence from US industry data. Economic Review - Federal Reserve Bank of San Francisco, 1-15. https://doi.org/10.1111/j.1468-0475.2007.00402.x

Chamorro-Premuzic, T., \& Arteche, A. (2008). Intellectual competence and academic performance: Preliminary validation of a model of. Intelligence, 36(6), 564-573. https://doi.org/10.1016/j.intell.2008.01.001

Durrah, O., Alhamoud, A., \& Khan, K. (2017). Positive psychological capital and job performance: The mediating role of job satisfaction. International Journal of Entrepreneurial Behavior \& Research, 23(6), 998-1016.

Engko, C. (2006). Effects of Individual Performance Against Job Satisfaction With Self Esteem and Self Efficacy as an intervening variable. National Symposium Accounting, 9 Padang. K-AMEN 06.

Fu, W., \& Deshpande, S. P. (2014). The impact of caring climate, job satisfaction, and organizational commitment on job performance of employees in a China's insurance company. Journal of Business Ethics, 124(2), 339-349.

Gairola, S. C. (2015). Assessment of Job Performance of Forest Guards in India: Relationship With Job Motivation, Satisfaction, Stress and Other Critical Factors. Indian Forester, 141(3), 235-246.

Gasaymeh, A. M., Al-hasanat, H., Kraishan, O., \& Abutayeh, K. (2017). Motivational Factors Affecting the Integration of Information and Communication Technology (ICT) in Education by Faculty Members: A Developing Country Perspective. International Journal of Education, 9(3), 168-182. https://doi.org/10.5296/ije.v9i3.11667

Goodhue, D. L., \& Thompson, R. L. (1995). Task-technology fit and individual performance. MIS Quarterly, 213-236. https://doi.org/10.2307/249689

Hakim, A. (2015). Contribution of competence teacher (pedagogical, personality, professional competence and social) on the performance of learning. The International Journal of Engineering and Science, 4(2), 1-12.

Hersey, P., Blanchard, K. H., \& Johnson, D. E. (2007). Management of Organizational Behavior: Leading Human Resources. Prentice Hall.

Huda, S., \& Laju, I. K. (2018). The Influence of Motivation Work and Competence on Performance of Mathematics Teachers With Innovation as Intervening Variable. International 
Information Institute (Tokyo). Information, 21(2), 539-546.

Kreitner, R., \& Kinicki A. (2000). Organizational Behavior (5th ed.). Boston: Mc Graw-Hill. Lantip, D., \& Riyanto. (2011). Information Technology Education. Yogyakarta: Gava Media.

Lee, C. K., Reisinger, Y., Kim, M. J., \& Yoon, S. M. (2014). The influence of satisfaction on the volunteer motivation, attitudes, and support for a mega-event. International Journal of Hospitality Management, 40, 37-48. https://doi.org/10.1016/j.ijhm.2014.03.003

Lucky, E. O. I., \& Yusoff, N. B. M. (2015). Evidence on teaching qualifications, characteristics, competence and lecturer performance in higher institutions in Nigeria. International Journal of Management in Education, 9(2), 129-150. https://doi.org/10.1504/IJMIE.2015.068758

Luftman, J., Lyytinen, K., \& Ben Zvi, T. (2017). Enhancing the measurement of information technology (IT) business alignment and its influence on company performance. Journal of Information Technology, 32(1), 26-46. https://doi.org/10.1057/jit.2015.23

Luna-Arocas, R., \& Morley, M. J. (2015). Talent management, talent mindset competency and job performance: the mediating role of job satisfaction. European Journal of International Management, 9(1), 28-51. https://doi.org/10.1504/EJIM.2015.066670

Mafini, C., \& Dlodlo, N. (2014). The relationship between extrinsic motivation, job satisfaction and life satisfaction amongst employees in a public organization. SA Journal of Industrial Psychology, 40(1), 01-12.

Mangkunegara, A. P. (2004). Human Resource Management. The first printing company, Bandung. PT. Teens Rsodakarya.

Mathis, R. L., \& Jackson, J. H. (2006). Human Resource Management: Resource Management. Human Resources, Angelia Dian translation, Jakarta.

Mulyasa. (2011). School Based Management, concepts, and strategies. Implementation. Bandung: PT Young Rosdakarya.

Muterera, J., Hemsworth, D., Baregheh, A., \& Garcia-Rivera, B. R. (2018). The leader-follower dyad: The link between leader and follower perceptions of transformational leadership and its impact on job satisfaction and organizational performance. International $\begin{array}{llll}\text { Public Management } \quad \text { Journal, } & \text { 21(1), }\end{array}$ https://doi.org/10.1080/10967494.2015.1106993

Nasir, M. J. A., Wiyono, B. B., \& Supriyanto, A. (2017). The Relationship between Motivation, Organizational Commitment and Competence with Job Satisfaction and Lecturers Performance. International Journal of Learning and Development, 7(3), 165-187. https://doi.org/10.5296/ijld.v7i3.11688

Ölçer, F., \& Florescu, M. (2015). Mediating effect of job satisfaction in the relationship between psychological empowerment and job performance. Business Excellence and Management, 5(1), 5-32. 
Prasetio, A. P., Aziz, E., Fadhilah, D. D., \& Fauziah, A. F. (2017). Lecturers 'Professional Competency and Students' Academic Performance in Indonesia Higher Education. International Journal of Human Resource Studies, 7(1), 86-93. https://doi.org/10.5296/ijhrs.v7i1.10902

Republic of Indonesia. (2005). Law on Teachers and Lecturers No. 14. Jakarta.

Robbins, S. P. (2006). Organizational behavior. Interpretation: Benjamin Molan (10th ed.). Publisher PT. The index, Gramedia Group, Jakarta.

Rusdi, S. D., Hassan, R., Munir, Z. A., \& Mohamad, S. S. (2017). Information and Communication Technology (ICT) Adoption Factors and Its Influence on Employees' Performance in SMEs. Advanced Science Letters, 23(8), 7841-7844. https://doi.org/10.1166/asl.2017.9590

Sajjad, A., Ghazanfar, H., \& Ramzan, M. (2013). Impact of motivation on employee turnover in the telecom sector of Pakistan. Quarterly Journal of Business Sudies, 5(1), 76.

Shah, M. J., Akhtar, G., Zafar, H., \& Riaz, A. (2012). Job satisfaction and motivation of teachers of public educational institutions. International Journal of Business and Social Science, 3(8).

Siagian, S. P. (2008). Manajemen Sumber Daya Manusia (Edisi. Pertama). Jakarta: Binapura Aksara.

Simanjuntak, M., \& Ritonga, A. I. (2018). The Impact of Competence on Extrinsic And Intrinsic Motivation And Performance Lecturer Of Merchant In Indonesia. International Information Institute (Tokyo). Information, 21(2), 547-554.

Sjahruddin, H., \& Normijati, A. A. S. (2013). Personality effect on organizational citizenship behavior (OCB): trust in manager and organizational commitment mediator of organizational justice in Makassar City Hospitals (Indonesia). European Journal of Business and Management, 5(9), 95-104.

Sriekaningsih, A., \& Setyadi, D. (2015). The Effect of Competence and Motivation and Cultural Organization towards Organizational Commitment and Performance on State University Lecturers in East Kalimantan Indonesia. European Journal of Business and Management, 7(17), 208-220.

Sundaram, S., Schwarz, A., Jones, E., \& Chin, W. W. (2007). Technology use on the front line: how information technology enhances individual performance. Journal of the Academy of Marketing Science, 35(1), 101-112. https://doi.org/10.1007/s11747-006-0010-4

Sutabri, T. (2014). Pengantar Teknologi Informasi. Edisi Pertama. Penerbit. Andi. Yogyakarta.

Theoharis, D., Katavelos, A., Tsekouropoulou, V., \& Tegkelidou, E. (2016). The impact of leadership type, employee motivation and job satisfaction on the performance of Greek Lifelong Learning Training. International Journal of Electronic Customer Relationship 


\section{Macrothink}

World Journal of Business and Management

ISSN 2377-4622 2018, Vol. 4, No. 1

Management, 10(1), 39-53. https://doi.org/10.1504/IJECRM.2016.079382

Toban, C., \& Sjahruddin, H. (2016). The Antecedent and Consequence of Organizational Commitment and Job Satisfaction. Journal of Business and Management Sciences, 4(2), 26-33. https://doi.org/10.12691/jbms-4-2-1

Wahyuni, D. U., Christiananta, B., \& Eliyana, A. (2014). Influence of organizational commitment, transactional leadership, and servant leadership to the work motivation, work satisfaction and work performance of teachers at private senior high schools in Surabaya. Educational Research International, 3(2), 82-96.

Yuen, K. F., Loh, H. S., Zhou, Q., \& Wong, Y. D. (2018). Determinants of job satisfaction and performance of seafarers. Transportation Research Part A: Policy and Practice, 110, 1-12. https://doi.org/10.1016/j.tra.2018.02.006

\section{Copyright Disclaimer}

Copyright for this article is retained by the author(s), with first publication rights granted to the journal.

This is an open-access article distributed under the terms and conditions of the Creative Commons Attribution license (http://creativecommons.org/licenses/by/3.0/). 